\title{
The Use of Problem-Based Instruction Strategy (PBIS) in Gas Laws Class: A Gender Academic Performance Difference
}

\author{
Popoola, Racheal Adewumi \\ Researcher, Science Education Department, \\ University of Ilorin, Ilorin, Nigeria
}

\author{
Prof. Olorundare, A. Solomon \\ Science Education Department, \\ University of Ilorin, Ilorin, Nigeria
}

\section{ABSTRACT}

The study is an aspect of an unpublished Master thesis which employed quasi-experimental design to investigate the gender academic performance difference in chemistry among senior secondary school students in Nigeria. The study sampled 165 students and used PBIS to teach the gas laws among the sampled students. The research used Gas Law Achievement Test (GLAT) and a researcher-designed problem-based instructional material as instruments. The data obtained were analyzed using the t-test statistical analysis. Only one research question and one hypothesis guided the study. Finding reveals there was no significant difference between male and female students taught the gas laws using PBIS. The study has implications for the teaching and learning of chemistry.

KEYWORD: problem-based instruction, gas law, academic performance, chemistry curriculum

\section{INTRODUCTION}

Chemistry is defined as the science that systematically studies the composition, properties, and uses of matter. It is assumed to be essential to almost all fields in science and technology. For instance; the knowledge of chemistry is brought into play in the manufacturing of fertilizers, herbicides, insecticides, drugs, and fungicide.

One of the most popular topics in the senior school chemistry certificate examination is gas laws. The Nigeria senior school chemistry curriculum is formulated around four central themes organized in a spiral form and across the three years of senior secondary school education. The topics are; chemistry and industry, the chemical world, chemistry and environment, and the chemistry of life (Federal Ministry of Education FME, 2007).Gas laws as a topic come under the theme of the chemical world listed for the study of gas laws in the chemistry curriculum.
The overall performance of Nigerian secondary school student, the senior school certificate examinations in chemistry over the years has not been encouraging. The summary of the enrolment result and the chief examiner report on the West Africa Senior School Certificate conducted in Nigeria within the period of 2006-2014 are presented in Table1

\begin{tabular}{|c|c|c|c|}
\hline Year & $\begin{array}{c}\text { Total Sat } \\
\text { Percentage }\end{array}$ & $\begin{array}{c}\text { Total } \\
\text { Credit } \\
(\mathbf{A 1}-\mathbf{C 6})\end{array}$ & $\begin{array}{c}\text { Pass } \\
\text { percentage } \\
(\mathbf{A 1}-\mathbf{C 6})\end{array}$ \\
\hline $\mathbf{2 0 0 6}$ & 308,104 & 170,670 & 55.30 \\
\hline $\mathbf{2 0 0 7}$ & 422,681 & 194,284 & 45.90 \\
\hline $\mathbf{2 0 0 8}$ & $418,423(98.0)$ & 185,949 & 44.44 \\
\hline $\mathbf{2 0 0 9}$ & $468,546(98.0)$ & 204,725 & 43.69 \\
\hline $\mathbf{2 0 1 0}$ & $465,643(97.5)$ & 236,059 & 50.70 \\
\hline $\mathbf{2 0 1 1}$ & $565,692(98.25)$ & 280,250 & 49.54 \\
\hline $\mathbf{2 0 1 2}$ & $627,302(97.77)$ & 270,570 & 43.13 \\
\hline $\mathbf{2 0 1 3}$ & $639,296(98.36)$ & 462,517 & 72.34 \\
\hline $\mathbf{2 0 1 4}$ & $636268(98.79)$ & 397,649 & 62.49 \\
\hline
\end{tabular}

Table 1: Achievement of WAEC candidates in chemistry between 2006 and 2014 (Source: WAEC)

According to Chegwidden (2006), problem-based instructional strategy or as established by Howard Barrows in the year 1960's as part of the education of physicians in medical school. Problem-based instructional performance strategy is a strategy that Neild (2004) defined as a set of problem provided to small groups of students to try to solve, the problems students discuss each problem among the small units retrieves their prior knowledge related to the problem and search for new information that helps in solving 
the problems. The PBIS aim is to assist students in developing rich cognitive models when solving the problem. The teachers act as facilitator and organizer (Mckimm, 2003). Savin-Baden (2006) argues that teachers aimed when using problem-based instructional are to develop their student selfindependent learning and reasoning.

A problem-based performance strategy is an alternative to the unsuccessful conventional method of teaching. Several types of research have been carried out on the popularity of different methods of teaching. Ayot and Patel (1987) wrote that despite that the lecture methods do not cater for realizing the aims of teaching all subjects, and it is not helping the learner to understand all that needs to be understood, it is almost dominant today, and it is likely by the majority of teachers.

Wilson (2004) investigated the effect of two teaching methods that is traditional lecturing method on student's cognitive achievement and problem-solving skills in biology. He showed that the treatment groups performed significantly better than the control group.

Olatoye, Aderogba and Aanu (2012) investigated the main and interaction effects of cooperative and individual teaching methods in senior secondary schools students' performance in organic chemistry. Results revealed that there was a significant main effect of cooperative learning on students' achievement in chemistry. This shows that the cooperative learning is effective in enhancing student achievement in organic chemistry. Both cooperative and individualized methods significantly improved students' performance in organic chemistry.

Gender is a state of being a male or a female. Gender is a cultural construct that distinguishes the roles, behavior, mental and emotional characteristics between females and males developed by the Society (Udosoro, 2011). Umoh (2003) defined gender as a psychological term used in describing behaviors and attributes expected of individuals and attributes expected of individuals by being born as either a male or female.

Gender is also the properties that distinguish organism by their sexual roles as female or male (Abubakar\&Uboh, 2010). Okeke (2003) noted that the study of gender means the analysis of the relationship between men and women including the division of labors, access to resources and other factors which are determined by the society as opposed to being determined by their sex.

Many researchers have provided reports that there are no longer distinguishing differences in the cognitive, affective and psychomotor skill achievements of students in respect of gender (Arigbabu\&Mji, 2004; Bilesanmi - Awoderu, 2006; David\& Stanley, 2000; Din, Ming, and Esther 2004; Freedman, 2002). However, Billing (2000); Eccles, Lord, Roeser, Barber, and Jozefowicz1997); Hyde and Mckinley (1997), in their studies found that male students performed better than the female learners in the cognitive, affective and psychomotor skill achievements.

Odebunmi (2003) conducted a study at Ladoke Akintola University of Technology involving 2500 students randomly selected from part one to four. Data was obtained using a questionnaire and data was analyzed using simple percentage and t-test. It was discovered that there was real significance difference in male and female student's attitudes towards the usage of the library. Similarly, Bajah (1997) conducted a study on the influence of gender and environment among chemistry students; it was discovered that the male students are superior to female students in school performance.

Researchers found on gender studies have indicated that attitudes toward science education differ between males and females. A declining interest in chemistry and under-representation of females in the chemical science was found (Jacobs, 2000: cited in Banya, 2005). Self-confidence toward chemistry, the influence of role models, and knowledge about the usefulness of chemistry affect the decision of young female students about the study of chemistry (Banya, 2005). In the event of young female students finding difficulty in constructing knowledge of chemistry, self-confidence is lowered with subsequent alternation of attitudes toward chemistry (Banya, 2005). Despite the studies and the recommendations made, the attitudes of young female students toward science and chemistry are still then positive than that of the male students.

Mackintosh (1998) posits that there was no sex difference in general intelligence. Mackintosh proposed that general intelligence should be defined as reasoning ability and that the best measures of this are the progressive matrices. 


\section{www.ijtsrd.com}

Durosaro (2011) noted that gender equally projects the properties that distinguish and classify organisms by their sexual and cultural and psychological attributes of men and women through their socioeconomic contributions, expectations, and limitations. Thus, the concept of gender does not support or suggest the dominance of the male over the female or vice versa in academic and other human resource development and utilization of competencies and endowed capabilities of both sexes.

Other researchers had also shown a decline in the differences between the genders in the past few decades on a standardized test, suggesting that the more exposure that women are getting to mathematics and science classes the better their scores. Even though this research puts into questions whether gender differences still exist in academic achievement, many research studies are still finding differences in performance as well as several interests in the area related to mathematics.

Studies on gender differences in chemistry performance have continued to yield inconsistent results (Usman\&Memem. 2007). The results of some studies indicate that male students achieve significantly better than the girls (Usman\&Libah, 2007). Whereas some other studies reveal no significant difference in the achievement of the two genders (Loofa, 2001), where these differences exist between the boys and the girls, it has usually been attributed to different exposure of males and females to experiences relevant to chemistry learning. This is occasioned by the traditional cultural attitude towards the female gender which restricts them from activities considered masculine (Okeke, 1990)

Samuel and John (2004) examined how the cooperative class experiment (CCE) teaching methods affect students' achievement in chemistry. They found that there was no significant difference in gender achievement between the experimental and control groups, but girls had a slightly higher mean score than boys did. Busch (1995) reported that female students had significantly lower self-efficacy than males on chemistry-related and other traditionally maledominated subject including a computer. Other researchers on the interrelationship of gender and chemistry have reported no significant gender influence on achievement in chemistry.

Agwagah and Harbor-Peters (1994) have reported that little differences are identified between males and females in chemistry achievement at ages 9 through 13 years but at age 11, females perform poorer than the males. Olatoye, Aderogba and Anu (2012) opined that the interaction effect of treatment, gender and self-concept on students' performance in organic chemistry is not significant when using cooperative and individualized teaching methods. However, cooperative method was found to be significantly better than individualized method

Chi-Chan (1997) investigated the effect of classroom goal structures on children's goal orientation, mathematics achievement, and intrinsic motivation. $\mathrm{He}$ also assessed gender effects and the interaction effects between goal structure and gender in these learning situations on the variables related to mathematics learning. The results showed no significant gender effects on the variables of goals orientation, mathematics achievement, intrinsic motivation, and beliefs about failure. DrzewieckiandWestberg (1997) carried out a survey of high school students to better understand how students' attitudes toward mathematics differ by gender and by grouping technique used for mathematics instructions and found that there was no significant main effect for gender and instructional method.

Given the above background, this study investigated the difference(s) the existed between male and female students academic performance in the Senior Secondary School chemistry using PIBS. The choice of PIBS and the Gas Laws was purposive to make the study unique and different from the previous studies on the gender academic achievement. Besides, the concept of gas law is selected because it has been identified as one of the very difficult concepts in senior secondary school chemistry curriculum (NERDC (1993).

It also helped to found out if gender difference does not exist based on the topic and the method of instruction as observed in physics by Crouch, Watkins, Fagen and Mazur (2007). Therefore, only one research question was raised, and one hypothesis tested to guide the study.

\section{Research Question}

Is there any significant difference between the male and female students taught using problem-based instructional strategy? 


\section{Research Hypothesis}

There is no significant difference between the performance of male and female students taught using problem- based instructional strategy.

\section{Research design}

This study was a quasi-experimental research designed to determine the effect of problem-based instructional strategy on senior school students' performance in chemistry. The quasi-experimental study is considered useful when a researcher wants to collect data on phenomena to know the difference between the control and the experimental group.

The design of the research is shown below

$\begin{array}{llll}\text { Experimental group } & \mathrm{O} 1 & \mathrm{X} & \mathrm{O} 2 \\ \text { Control group } & \mathrm{O} 3 & & \mathrm{O} 4\end{array}$

$\mathrm{X}$ means treatment for the experimental group (those taught using problem-based instructional strategy)

O1 means pre-test for the experiment group before the introduction of the problem-based instructional approach. (PBLS)

$\mathrm{O} 2$ means posttest for the experimental group.

O3 means pre-test for the control group

O4 means post-test for the control group

\section{Sample and Sampling Techniques}

All senior secondary school students two in a Local Government Area of Kwara State, Nigeria constituted the population. A sample of two schools was purposively selected using the simple random sampling technique. The schools were chosen based on the following criteria that the schools were a coeducational, that is male and female constitute the learner.

In each of the schools, an intact class was used. Senior School two (SSII) students participated in the study because they were not preparing for Senior School Certificate Examinations (WASSCE) and National Senior School Certificate Examination (SSCE) at the time of the study and they had learned some fundamental concepts in gas laws.

\section{Research Instruments}

Two instruments were used for this study; they are achievement test on gas laws and a researcherdesigned problem-based instructional material. The problem-based learning material was utilized for the experimental group; problem-based instructional manual and achievement test on gas law

\section{Validation of Research Instruments}

The instrument was given to the two science education experts in a Nigerian University for validation. The reliability of the instrument was determined by the test-retest method for three weeks interval in which the test items were used for students of another school that is not participating in the study. The reliability was determined using Pearson Product Moment Correlation statistics. A coefficient of 0.81 was obtained.

\section{Procedure for Data Collection}

A letter of introduction of the researcher seeking permission to carry out the research and administer test items was presented to the principals of the selected secondary schools. The researcher administered a pretest to both control and experimental group. The researcher carried out the main treatment which lasted for six weeks, while the research assistant taught the control group. Post-test was administered to both experimental and control group at the end of the treatment.

The experimental group was taught gas laws by using problem-based instructional strategy. It is a learnercenter method of teaching, and the researcher's role was to facilitate learning regarding organizing, monitoring, and supervising learning. In this group, students were given roles according to their performance in the pre-test, the group leader was selected for each group, the timekeeper, the secretary and code of conducts was given to guard against misbehavior in the class. The duties of the group leader were to oversee all conduct in each group; the secretary wrote the report of each activity of each lesson and any other assigned work given by the researcher, and she presented the report as demanded by the researcher. The timekeeper kept the time to stop each activity in the group. 
In the experimental group, gas laws achievement test was given on individual basis in other to gather data to be able to vary the result of PBIS method on students' performance on gas laws in chemistry. The control group students were not exposed to the treatment when taught gas laws. At the end of the exercise, Gas Law Achievement Test (GLAT) was administered to assess their performance.

\section{Data Analysis Techniques}

The data collected from the post-test of the experimental group were analyzed using the t-test statistical tool to answer the research question and test the hypothesis. The research hypothesis was tested for statistical significance at 0.05 level of significance.

\section{Results and Discussion}

Research Question 1: Is there any significant difference between the male and female students taught using problem-based instructional strategy?

HO1: There is no significant difference between the performance of male and female students taught using problem- based instructional strategy.

To test hypothesis $\mathrm{HO}_{1}$, the obtained scores of male and female students in the experimental group (students taught using problem-based instructional strategy) were collated. The set of data was then subjected to independent t-test using SPSS 21.0 and computed at the level of significance of 0.05 . The analysis output is shown in Table 1.

\begin{tabular}{|c|c|c|c|c|c|c|c|}
\hline Gender & $\begin{array}{c}\text { No of } \\
\text { Students }\end{array}$ & Mean & $\begin{array}{c}\text { Standard } \\
\text { Deviation }\end{array}$ & Df & $\begin{array}{c}\text { Cal } \\
\text { t-value }\end{array}$ & Sig & Decision \\
\cline { 1 - 4 } Male & 24 & 29.29 & 4.21 & 6 & \multirow{2}{*}{1.820 .21 N.S } \\
\cline { 1 - 4 } Female & 39 & 28.59 & 6.02 & 1 & \\
\hline
\end{tabular}

$\mathrm{P}<0.05$

Table 1 : t-test Analysis Showing Difference in Scores of Male and Female Students Taught Using Problem-based Instructional Strategy

It can be seen from Table 1 that the calculated significance of 0.21 with 61 degrees of freedom was greater than the 0.05 level of significance. Therefore the research hypothesis one was retained. This implies that there was no significant difference in the academic performance of male and female students taught with problem-based instructional strategy. This finding is at variance with Eccles, Lord, Roeser, Barber, and Jozefowicz(1997); Hyde and Mckinley (1997) but agreed with Bilesanmi - Awoderu, (2006); David and Stanley(2000); Din, Ming, and Esther (2004); Freedman(2002). The submissions by these various authors concerning the finding of this study indicate that Usman and Memem. (2007) was correct that research studies outcome on gender academic difference in chemistry is not consistent.

\section{CONCLUSION}

Given the detailed analysis, finding and discussion above, there was no significant difference in academic performance of students in PBIS class based on gender. This does not imply the students in this group had the same scores in the gas laws achievement test.
There may be differences in scores, but it is not significant to conclude that a particular gender is better academically than the other.

\section{Implication for Further Study}

The outcome of this study has implications for the teaching and learning of chemistry and other related science subjects like physics where students learn gas laws. The result of the study implies both male and female students have the same academic potential if they learn under the same condition. Therefore, teachers should stop discriminating against any gender. The study could also be replicated in another school using different students and teachers.

\section{REFERENCES}

1) Abubakar, R.B, \&Uboh, V. (2010). Breaking the gender barrier in enrolment and academic achievement of science and mathematics students. Akoka. Journal of Pure and Applied Science Education. 
2) Agwagoh, U.N., and Harbour - peters, V.F. (1994).Gender difference in Mathematics Achievement.Journal of Education and Psychology in Third world Africa,1(1), 19

3) Arigbabu, A.A. \&Mji, A. (2004). Is Gender a factor in performance among Nigeria preservice Teachers?Sex role, 51(11\&12), 749.

4) Ayot, M.O., \& Patel, M.M. (1987).Instructional Methods Series on provision of leadership training in Teacher Education supported by ODA through British Council HED school. The Kenyatta University of London, Institute of Education.

5) Ali, R. (2010). Effect of using problem-solving method in Teaching Mathematics.

6) Asian Social Science 6(2). Retrieved from http://ccsenet.org/journal /index.php/ass/Article/viewfile/5004/4170.

7) Bajah, S.T. (1997). Correlate students' Extinsil School environment. Farwith level of attainment in a standardize test in chemistry. Journal of Science. Teachers' Association of Nigeria, 18(1) $49-50$.

8) Banya, S.K. (2005). Study of Factors Affecting Attitude of young students toward chemistry at the High School Level. Ph.D. Dissertation.College of science and Technology of the University of Southern Mississippi.

9) Bilesanmi - Awoderu, V.B. (2006), Effect of computer-assisted instructandsimulation/Games on the Academic Achievement of secondary School students in Biology. Sokoto Educational Review 8(1). $49-60$.

10) Busch, T. (1995).Gender differences in selfefficacy a performance among students of Business Administration.Scandinavian Journal of Education Research 39, 311 - 318.

11) Cheguidden, W. (2006). A problem-based learning pathway for medical student: Improving the process through action research Ann Acad. Med. 35:642-646.

12) Chin .C. \&Chia, L. G. (2004). Problem-based learning; using students' questions to drive knowledge construction, Science Education, 88(5), 707-727

13) Crouch, C.H, \& Mazur, E. (2001). Peer instruction: Ten years of experience and results

14) American Journal of Physics, 69(9), 970-977. DOI: $10.1119 / 1.1374249$

15) David, K. \&Stawey, H.L. (2000). Effect of Gender on computer-based chemistry
16) Problem-solving.Electronic Journal of Science Education. 4 (4) ISSN 224- 0524

17) Din,Y.Y., Ming, M.C., Esther,S.H. (2004). Hong Kong Students Achievement in OECD-PISA study: Gender Differences in Science content, Literary skills and Test Item formats, International Journal of Science and Mathematics Education,2(1),91-106.

18) Durosaro, D.O. (2002). Refocusing Education in Nigeria: Implications for funding and Management In S.Oriafor, P.O.E. Nwokolo and G.C. Igborgbor (Eds).Refocusing Education in Nigeria. 33 - 37 Benin City, Nigeria: Da-Sylvia influence.

19) Drzewiecki, L.A., \&Westberg, K.L. (1997). Gender difference in High School

20) Students Attitudes toward Mathematics in Traditional Versus Cooperative Group.The National Research Centre on the Gifted and Talented.Pring Newsletter.

21) Eccles, J.S., Lord, S.E., Roesen R.W., Barber, B.L. \&Jozefowecz, D.M. (1997). The Association of School Transitions in Early Adolescence with Developmental Trajectories through High School.In J. Scholenberg\& J. Maggi \& K. Hurrelmann (Eds), Health Risks and Developmental Transitions during Adolescence (PP 283 - 320). New York: Cambridge University Press.

22) Ekepte,O.A.(2002). Enhancing understanding of chemical arithmetic in learning of chemistry.African Journal of Research in Education vol2 pg 162-165.

23) Federal Republic of Nigeria (2004).National Policy on Education. Lagos: (NERDC).

24) Freedman, M.P. (2002).The influence of Laboratory Instruction on Science Achievement and Attitude towards science across Gender differences.Journal of Women and minorities in science and Engineering.8 (2). 50.

25) Hyde, J.s., Mckinley, N.M. (1997). Gender difference in cognition.Results from MeatAnalysis.Incaplan, P.J., Grawford, M., Hyde, J.S. \& Richardson, J.T.E. (Eds).Gender difference in Human cognition (PP 30 - 51). New York: Oxford Press.

26) Jacobs, J.E., Lanza, S., Osgood, D.W., Eccles, J.S. $\&$ Wigfield, A. (2000). Changes in children's selfcompetence and values: Gender and Domain differences across grades one through twelve Child development. 73 (2), $509-525$. 
27) Loofa, J.K. (2001).Sex, Age and performance in chemistry. Instructional Science, 18,119 - 147.

28) Lynn, R. (1998). Sex differences in intelligence: A rejoinder to Mackintosh, Journal of Biosocial Sciences, 30, 529 - 532.

29) NERDC (1993). National Education Research Council. Report on the workshop on difficult concepts in science and Mathematics.

30) Mackintosh, N.J.(1998). Reply to Lynn, Journal of Biosocial Science, 30, 533-539.

31) Mckimw, J. (2003). Facilitating Learning: Teaching and Learning methods Retrieved on April 22, 2013, form http://www.faculty. London earner A.C. $\quad$ UK //..// small-group teaching.

32) Neild (2004).Defining, measuring and maintaining the quality of problem-based learning. Australian University Quality Forum 2004.

33) Odebunmi, F.O. (2003). Attitude of students of theLagokeAkintola University of Technology, Ogbomoso towards the used of library. An Unpublished, B.Ed (ed) submitted to the Department of Education. University of Ado Ekiti.

34) Okeke,E.C.(2003). Gender and Sexuality Education: Bridging the Gap in Human Resource Development. Journal of Curriculum Organization of Nigeria 10(1), 117-120.

35) Olatoye, R.A., Aderogba, A.A., \&Aann, E.M (2011).Effect of cooperative and individualized teaching methods on senior secondary school students' achievement in organic chemistry. The Pacific Journal of Science and Technology, 12(2).

36) Samuel, W.W. \& John, G.M., (2007).Effect of cooperative class experiment teaching method on secondary school students' chemistry achievement in Kenya NakaruDistrict. International Education Journal 5(1), 26 - 35.

37) Udousoro, U.J. (2011). The effects of gender and mathematics ability on academic performance of students in chemistry. An international multidisciplinary Journal, Ethiopia. 5(4), 201 213.

38) Savin - Baden, M. \&Wilkie, K. (2006). (eds) Problem-based learning onlinemaiden headmccraw Hill.
39) Umoh, C.G., (2003). 5(4), 201 - 213.A theoretical analysis of the effects of gender and family on human resource development. Journal of curriculum organization of Nigeria, 10 (1), 1 4.

40) Usman and Uba, A.I. (2007). Improving students' achievement in further chemistry using team teaching approach. Review of Education, 18(10), $15-29$.

41) Usman, K.O. \& Memeh, I.M. (2007). Using guided scoring teaching strategy to improving students' achievement in chemistry at secondary school level in Nigeria. Journal of Science Teacher Association of Nigeria.

42) Wilson, C. (2004). Intervention central-prior knowledge: Activating the known 71. $677-681 \mathrm{~A}$. Retrieved December 5, 2012 form http://www.intervention central.org/htmdocs/interventions/rdngcompr/prio rknows.html. 